\title{
Article \\ Photovoltaic Prediction Software: Evaluation with Real Data from Northern Spain
}

\author{
David González-Peña ${ }^{1, *}$, Ignacio García-Ruiz ${ }^{2}{ }^{\mathbb{C}}$, Montserrat Díez-Mediavilla ${ }^{1}, \mathrm{M}^{\mathrm{a}}$. Isabel Dieste-Velasco ${ }^{1}$ \\ and Cristina Alonso-Tristán ${ }^{1}$ (D) \\ 1 Research Group Solar and Wind Feasibility Technologies (SWIFT), \\ Electromechanical Engineering Department, Universidad de Burgos, 09006 Burgos, Spain; \\ mdmr@ubu.es (M.D.-M.); midieste@ubu.es (M.I.D.-V.); catristan@ubu.es (C.A.-T.) \\ 2 Engineering Department, Universidad Pública de Navarra, 31006 Pamplona, Spain; \\ ignacio.garcia@unavarra.es \\ * Correspondence: davidgp@ubu.es
}

check for updates

Citation: González-Peña, D.; García-Ruiz, I.; Díez-Mediavilla, M.; Dieste-Velasco, M..I.; Alonso-Tristán, C. Photovoltaic Prediction Software: Evaluation with Real Data from Northern Spain. Appl. Sci. 2021, 11, 5025. https://doi.org/10.3390/ app11115025

Academic Editor: Harry D.

Kambezidis

Received: 10 May 2021

Accepted: 28 May 2021

Published: 29 May 2021

Publisher's Note: MDPI stays neutral with regard to jurisdictional claims in published maps and institutional affiliations.

Copyright: (C) 2021 by the authors Licensee MDPI, Basel, Switzerland. This article is an open access article distributed under the terms and conditions of the Creative Commons Attribution (CC BY) license (https:// creativecommons.org/licenses/by/ $4.0 /)$.
Featured Application: Featured Application: Several commercially available and free downloadable PV modelling software tools are compared with real data for three different photovoltaic power plants in operation over the past 12 years. Both annual and monthly results are analyzed.

Abstract: Prediction of energy production is crucial for the design and installation of PV plants. In this study, five free and commercial software tools to predict photovoltaic energy production are evaluated: RETScreen, Solar Advisor Model (SAM), PVGIS, PVSyst, and PV*SOL. The evaluation involves a comparison of monthly and annually predicted data on energy supplied to the national grid with real field data collected from three real PV plants. All the systems, located in Castile and Leon (Spain), have three different tilting systems: fixed mounting, horizontal-axis tracking, and dual-axis tracking. The last 12 years of operating data, from 2008 to 2020, are used in the evaluation. Although the commercial software tools were easier to use and their installations could be described in detail, their results were not appreciably superior. In annual global terms, the results hid poor estimations throughout the year, where overestimations were compensated by underestimated results. This fact was reflected in the monthly results: the software yielded overestimates during the colder months, while the models showed better estimates during the warmer months. In most studies, the deviation was below $10 \%$ when the annual results were analyzed. The accuracy of the software was also reduced when the complexity of the dual-axis solar tracking systems replaced the fixed installation.

Keywords: photovoltaic; RETScreen; SAM; PVGIS; PVsyst; PV*SOL; energy prediction

\section{Introduction}

The environmental commitments to which European countries have subscribed to make it essential to drastically reduce greenhouse gas emissions, to reduce energy consumption in both public and residential buildings, and to incorporate renewable energies as the main source of supply. Photovoltaic (PV) energy is a renewable energy that has undergone a faster development than any other and is now a mature and economically competitive technology [1].

Any technical analysis of renewable energy and its implementation requires computer tools. It is time-consuming to create new tools for each analysis when accessible tools exist. Reasonable predictions of PV system energy production levels are vital for continuous supply, from the perspective of both the consumer and the system integrator. These predictions should be attainable based on available or desired system sizing parameters, such as the model of the PV modules, performance rating, orientation, and power loss from wires. Specific commercially available, as well as free, downloadable prediction 
software tools exist for this purpose. With these software tools, we can calculate the energy production of a desired system, by simply computing the system sizing parameters.

Numerous reviews have focused on computer tools for PV system modeling and performance estimation. In this regard, Connolly et al. [2] presented a complete review of existing computer tools for analyzing the integration of renewable energy projects. Some of these software tools are extensively used as the basis for many scientific studies. For example, the work of Wijeratne et al. [3] included a comprehensive review of the software tools used in various studies for the simulation of PV systems. Undoubtedly, the performance of such PV tools determines the quality of the results obtained in the above-mentioned works. However, few studies have assessed the performance of different available PV simulation software tools against real-world data of PV system energy production.

Lee et al. [4] validated four PV tools (PVsyst, Hybrid Optimization Model for Multiple Energy Resources "HOMER", RETScreen and, System Model Advisor "SAM" Sunny Design), based on actual production data measured at six PV systems at the Desert Knowledge Australia Solar Centre (DKASC), a solar technology demonstration facility located at Alice Springs (Australia). Its systems were composed of modules of different PV technologies, i.e., monocrystalline, polycrystalline, amorphous silicon, and cadmium telluride (CdTe) thin-film modules. The installed power of the PV arrays ranged from $5.1 \mathrm{~kW}$ to $7 \mathrm{~kW}$. The modeling tools were found to be relatively accurate, with annual total average percentage differences between $-1.44 \%$ and $-4.93 \%$, depending on the type of installation. HOMER and RETScreen, in particular, provided the most accurate results, while PVsyst generally provided conservative results. Although, Sunny was the simplest of the models and provided the least accurate results.

Axaopoulos et al. [5] analyzed the performance of six software tools (Transient System Simulation Tool "TRNSYS", Archelios, Polysun, PVSyst, PV*SOL, and Photovoltaic Geographical Information System "PVGIS") using the real electrical energy generated by a grid-connected $19.8 \mathrm{kWp}$ photovoltaic installation located in Thrace (Greece). Their results revealed that all tools tended to overestimate the global irradiation received by the PV modules, but significantly underestimated the electrical energy generated by the installation. Specifically, the tool that showed the best overall performance was TRNSYS followed by Archelios. The results also showed that software based on or depending on the PVGIS irradiation database could be significantly inaccurate, especially if the study is performed for specific months or short-time periods.

Freeman et al. [6] validated four popular PV modelling tools (SAM, PVWatts, PVsyst, and $\mathrm{PV}^{*} \mathrm{SOL}$ Expert) against actual data of nine photovoltaic systems, which included three utility-scale systems and six commercial-scale systems. In their study, they expanded the results of previous work [7] in which only the SAM tool was evaluated. Regarding the annual performance of the tools, relative errors ranged from $1.4 \%$ to $-16.2 \%$. In this case, PVWatts emerged as an outlier for the nine systems. Apart from the outliers, all annual errors were within $8 \%$. On the hourly scale, apart from two specific outliers all root mean square errors (RMSE) were less than $7 \%$ for all tools and all systems. This work provided disaggregated errors for the different PV installations, so it was not possible to establish which tool performed better.

Recently, de Souza Silva et al. [8] conducted a comparative study of different PV power simulation software tools (PVsyst, $\mathrm{PV} * \mathrm{SOL}$, and HOMER) using the production data measured at the $336.96 \mathrm{~kW}_{\mathrm{p}}$ PV plant of the University of Campinas (Brazil). The results revealed that $\mathrm{PV} * \mathrm{SOL}$ presented more conservative results and HOMER was the most optimistic software. According to the annual errors obtained by comparing the output of the software tools and the actual values of the PV plant, PVsyst showed the best performance, with an error of $1.02 \%$, followed by HOMER, with an error of $2.04 \%$. PV ${ }^{*} \mathrm{SOL}$ showed a higher, although a more conservative, error $(-10.38 \%)$.

With this background in mind, five of the most commonly used system sizing tools were evaluated in this study, i.e., RETScreen, Solar Advisor Model (SAM), PVGIS, PVSyst, and $\mathrm{PV} * \mathrm{SOL}$. In the first place, the characteristics of each of the programs under analysis in 
the study were described: geographical data needed, way to compute solar irradiation, the PV system simulation capacity, etc. The results of the simulation with computer programs are compared with real production data over one complete year of operation of three facilities located in Spain, each one with a different tracking system: fixed installation, installation with one axis sun-tracker and two-axis tracker PV system. The main novelty of the study is that data used to verify simulation came from grid tied facilities in operation: the data correspond with the actual system turnover values and was provided directly by the company that owned the facility. The lengthy data-collection period, from 2008 to 2020, allows us to discount the influence of either warm or cold years. In addition, annual comparisons have been complemented with a monthly analysis where the deviation error throughout the year is discussed.

\section{Methodology}

Five different software photovoltaic models: Photovoltaic Geographical Information System (PVGIS) [9], PVsyst [10], RETScreen [11], PV*SOL [12] and System Advisor Model (SAM) [13], are evaluated in this work. The AC energy generation estimates of each software package were compared with the real AC energy production data of three different types of PV plants. Table 1 details a comparison of the main features of each program, whether solar radiation databases can be used, as well as product libraries (PV module and inverter), the number of parameters that are required, difficulty of using the software, number of results calculated, shadow modeling, electrical loses and license costs.

Table 1. Software tools technical specifications.

\begin{tabular}{|c|c|c|c|c|c|}
\hline & PVGIS & PVSYST & SAM & $\mathrm{PV}^{*} \mathrm{SOL}$ & RETScreen \\
\hline $\begin{array}{l}\text { Solar } \\
\text { Radiation } \\
\text { Database }\end{array}$ & $\begin{array}{c}\text { Very complete } \\
\text { for Europe, } \\
\text { Africa and Asia. } \\
\text { Satellite data } \\
\text { interpolation models. }\end{array}$ & $\begin{array}{l}12 \text { databases of } \\
\text { different locations. } \\
\text { User expandable } \\
\text { theoretical models. }\end{array}$ & $\begin{array}{c}\text { User defined } \\
\text { expandable online } \\
\text { search. } \\
\text { Theoretical models. }\end{array}$ & $\begin{array}{l}\text { Meteonorm. } \\
\text { German Weather } \\
\text { Service (DWD). }\end{array}$ & $\begin{array}{l}\text { NASA. } \\
\text { User } \\
\text { expandable. }\end{array}$ \\
\hline $\begin{array}{l}\text { Product library: } \\
\text { PV module and } \\
\text { inverter }\end{array}$ & No & $\begin{array}{l}\text { Very complete and } \\
\text { expandable }\end{array}$ & Complete & $\begin{array}{l}\text { Very complete and } \\
\text { expandable }\end{array}$ & Outdated \\
\hline Inputs required & Very few & Many & Many & Many & Few \\
\hline Output Results & Basic results & $\begin{array}{l}\text { Many } \\
\text { energy-related and } \\
\text { economical results }\end{array}$ & $\begin{array}{c}\text { Many energy-related } \\
\text { and economical } \\
\text { results }\end{array}$ & $\begin{array}{c}\text { Many } \\
\text { energy-related and } \\
\text { economic results }\end{array}$ & $\begin{array}{c}\text { Basic } \\
\text { energy-related } \\
\text { and economic } \\
\text { results }\end{array}$ \\
\hline $\begin{array}{c}\text { PV facility } \\
\text { design }\end{array}$ & Simple & Complete & Simple/Complete & Complete & Simple \\
\hline Losses/shadows & Yes/No & Yes/Yes & Yes/Yes & Yes/Yes & Yes/No \\
\hline Difficulty & Low & Medium & Medium/High & Medium/High & Low/Medium \\
\hline Cost & Free & $\begin{array}{l}600 \text { CHF/year } \\
\text { (30 Day Trial) }\end{array}$ & Free & $\begin{array}{c}895 € \\
\text { (30 Day Trial) }\end{array}$ & $\begin{array}{c}869 € / \text { year } \\
\text { (Demo) }\end{array}$ \\
\hline
\end{tabular}

One of the greatest benefits of these programs is that preliminary studies of PV project feasibility may be performed even before fully developing the design of the PV plant. The main objective of this type of study is to estimate the energy generated with a low number of known parameters. Although the power plant can be described in detail in some of these programs, the comparison in this study is focused on a preliminary study, where only essential parameters have been defined: location, type of solar tracking technology, installed capacity, number of modules, and efficiency and peak power of the PV module and inverter. The parameters of each station are summarized in Table 2. All other parameters, such as wire and shadow losses, as and when required, can be set as default parameters or 
with the standard recommended values of the software manual. All the models implement different climate database options, either online or integrated, so the option recommended by each program was selected and compared when different options were available.

Table 2. Technical specifications of panels and inverters used in the PV facilities under study (System 1, System 2, and System 3).

\begin{tabular}{|c|c|c|c|}
\hline & $\begin{array}{c}\text { System } 1 \\
\text { (Palencia) }\end{array}$ & $\begin{array}{c}\text { System } 2 \\
\text { (Torquemada) }\end{array}$ & $\begin{array}{c}\text { System } 3 \\
\text { (Los Balbases) }\end{array}$ \\
\hline Sea Level (m) & $740 \mathrm{~m}$ & $742 \mathrm{~m}$ & $800 \mathrm{~m}$ \\
\hline Longitude & $4^{\circ} 30^{\prime} \mathrm{W}$ & $4^{\circ} 19^{\prime} \mathrm{W}$ & $4^{\circ} 3^{\prime} \mathrm{W}$ \\
\hline Latitude & $42^{\circ} 0^{\prime} \mathrm{N}$ & $42^{\circ} 2^{\prime} \mathrm{N}$ & $42^{\circ} 12^{\prime} \mathrm{N}$ \\
\hline Panel model & Fotona 180D & BP-7185S & Sunport 72M \\
\hline $\mathrm{V}_{\max }(\mathrm{V})$ & 36.8 & 36.5 & 35.89 \\
\hline $\mathrm{I}_{\max }(\mathrm{A})$ & 4.89 & 5.1 & 7.81 \\
\hline$W_{P}(W)$ & $180 \pm 1.3 \%$ & $185 \pm 2.5 \%$ & $280 \pm 3.0 \%$ \\
\hline Performance (\%) & $15 \%$ & $14-16 \%$ & $14 \%$ \\
\hline Number of panels & 216 & 546 & 51 \\
\hline Number of groups & 18 & 39 & 3 \\
\hline $\mathrm{V}_{\text {group }}(\mathrm{V})$ & 441 & 511 & 610 \\
\hline Facility Power $(\mathrm{kW})$ & 38.88 & 101.01 & 14.28 \\
\hline Inverter model & SMA: SMC 7000TL & Ingecom Sun 100 & $\begin{array}{c}\text { SMA: Sunny Boy } \\
\text { 4200TL HC }\end{array}$ \\
\hline Maximum power $(\mathrm{kW})$ & 7 & 100 & 4.4 \\
\hline Number of inverters & 6 & 1 & 3 \\
\hline $\mathrm{V}_{\mathrm{cc}}(\mathrm{V})$ & 700 & $405-750$ & 750 \\
\hline $\mathrm{I}_{\mathrm{CC}}(\mathrm{A})$ & 22 & 286 & 22 \\
\hline $\mathrm{V}_{\mathrm{ca}}(\mathrm{V})$ & 230 & $3 \times 400$ & 230 \\
\hline $\mathrm{I}_{\mathrm{ca}}(\mathrm{A})$ & 31 & 187 & 19 \\
\hline Performance (\%) & 98 & 96.8 & 96 \\
\hline Sun Tracking System & Fixed & 1-axis & 2-axis \\
\hline $\begin{array}{l}\text { Tilt angle or sun } \\
\text { tracking limits }\end{array}$ & $20^{\circ}$ & $15^{\circ} / 55^{\circ}$ & $\begin{array}{c}-130^{\circ} / 130^{\circ} \\
0^{\circ} / 80^{\circ}\end{array}$ \\
\hline Orientation & South $/ 180^{\circ}$ & South $/ 180^{\circ}$ & - \\
\hline
\end{tabular}

\subsection{PVGIS}

The Photovoltaic Geographical Information System (PVGIS) provides a map-based inventory of solar energy resource and an assessment of electricity generation from photovoltaic systems in Europe, Asia, Africa, and South America. The database includes monthly and yearly average values of the global irradiation on horizontal and inclined surfaces, as well as climatic parameters needed for an assessment of the potential PV electricity generation $[14,15]$. With the following applications, it is possible to choose between databases collected by satellite that includes data from 2005 to 2016: SARAH, NREL, CMSAF, ECMWF, and COSMO-REA6. It uses an interpolation of data models for geographic resolution.

Using PV-GIS, the PV facility can be described by selecting the type of solar tracking system, its integration or otherwise within the buildings, installed power, system performance, and PV panel technology (Si Crystalline CdTe, CIS o CIGS). PVGIS provides daily and monthly average global irradiation data and daily and monthly average PV power production. It can also be used to optimize the angles of orientation of the PV panels and their tilt.

The simplicity and free use of PVGIS mean that it is frequently used for initial energy estimations of PV facilities. The databases are widely implemented in Europe, Africa, and Asia with regular updates, and their reliability has been demonstrated in a large number of scientific papers [16-20]. 


\subsection{PVSYST}

PVSYST software is a European-based PV system predictor developed by the University of Geneva for the European Energy Center. It is suitable for studying, simulating and analyzing stand-alone and grid-connected PV systems. Additionally, it is also useful for solar-thermal systems and solar applications. PVSYST is a well-designed tool with an extensive number of features for detailing the PV system and includes an extensive database of different PV related products. PVSYST includes algorithms for thermal and wind effects calculation, wire losses and incidence angle modifier losses, albedo values, and a horizon adjustment capability. This software has received significantly high scores and recommendations in various comparative studies [15,21-23].

PVSYST imports meteorological and global irradiation data from Meteonorm and NASA-SSE. In addition, other external databases can be introduced in the study. PVsyst implements theoretical models for the calculation of both global irradiation on an inclined plane and diffuse irradiation $[24,25]$. The database of available PV panels, inverters, and batteries is very broad, is directly updated by the manufacturers, but can also be imported from the PHOTON database and even permits the definition of "ad hoc" panels of different technologies: mono-Si, poli-Si, and thin film. It is compulsory to introduce the design of the system: distribution of PV panels, and connection with the inverter, tilted angle and sun-tracking system specification. The incidence angle can be optimized and shadows and other elements can be introduced with PVSYST that may have an impact on the performance of the installation. Although the PV plant can be precisely described, when looking for a preliminary study, some parameters are not pre-defined, which complicates any definition of the basic study.

The main data outputs are annual PV production (MW) and the specific PV production $\left(\mathrm{kWh} / \mathrm{kW}_{\mathrm{p}}\right.$ year$)$, as well as the performance factor. A monthly diagram of standard production per installed $\mathrm{kW}_{\mathrm{p}}$ is generated, including the following information: power loss, total energy produced, the effective power to the output of the generator, the energy injected into the network, the electrical efficiency of the facility, and a table with the solar irradiation data (horizontal global irradiation, incident irradiation at the receptor). In addition, the tool generates a diagram of losses during the year, indicating the estimated losses due to temperature, wiring, inverter system, and shadows. It is a payment program, but a complete version is free for one month. Subsequently, the program functions in DEMO mode, with very limited options.

\subsection{System Advisor Model (SAM)}

System Advisor Model (SAM) [8] is provided by the National Renewable Energy Laboratory (NREL) of the U.S. Department of Energy. SAM provides a consistent framework both for analyzing and for comparing power system costs and performance across the range of solar technologies and markets, from PV systems for residential and commercial markets to concentrating solar power and large PV systems for utility markets. SAM combines an hourly simulation model with performance, cost, and finance models to calculate energy output, energy costs, and cash flows. The software can also account for the effect of incentives on cash flows. Most of SAM's inputs can be used as parametric variables for sensitivity studies [15,26-28].

SAM input consists of hourly weather data and the software can read files in either TMY2, TMY3 (typical meteorological year [29]), and EPW (energy plus weather data file) formats from over 20 sources [30] and data that the user may introduce. The program provides horizontal infrared radiation from sky, global horizontal radiation, direct normal radiation, and diffuse horizontal radiation, directly from the database, or calculated through various user-selected models, such as Hay [25], Perez [24,31], and Reindl [32].

SAM includes a wide database of PV panels and inverters and it is possible to define new elements. The complete design of the facility cannot be entered, but the estimated losses in each section can be indicated: DC and AC wiring, transformer efficiency, thermal 
and power losses from wires and the sun-tracking system. It also implements a position of the panel model to predict shadows in the solar plant.

As a result, the program provides a summary table with major energy and economic data of the facility and its temporal evolution. It is a very complete free program with great possibilities for the analysis of solar photovoltaic, thermal, concentration, wind, and geothermal energy projects of all sizes and complexity.

\subsection{RETSCREEN}

RETScreen is managed by the research center of Natural Resources Canada (NRCan). This software can be used to evaluate the energy production and savings, costs, emission reductions, financial viability, and risk for various types of renewable-energy and energyefficient technologies (RETs) [32-37]. In addition, the RETScreen software integrates a series of databases that help to overcome the costs and difficulties associated with gathering meteorological data, product performance data, etc. Hence, global meteorological data are incorporated in the RETScreen software. This meteorological database includes both the ground-based meteorological data and NASA's satellite-derived meteorological data sets.

RETScreen has a basic user-expandable PV panel. The database covers no other element of the PV facility. The following information must be inputted: type of panel (poly-Si, mono-Si, etc.), total PV installed power of facility, efficiency, estimated electrical losses, losses caused by shadows. The inverter data, defined by the user, are input power, performance and estimated losses.

The economic analysis of the system requires the definition of estimated operational life, initial investment, loans, and grants, and the program can be used to analyze various economic scenarios.

As output, it generates different tables and graphs: daily solar horizontal irradiation by month, the estimation of annual electricity production (MWh), environmental benefits ( $\mathrm{CO}_{2}$ emissions savings, equivalent in barrels of petroleum), return on investment period, evolution of the benefits over the operating life of the installation, internal rate of return (IRR), net present value (NPV), and unit cost of energy. In the most recent updated version, RETScreen Expert, has become a paid program.

\section{5. $P V^{*} S O L$}

$\mathrm{PV} * \mathrm{SOL}$ is software for planning, design, and simulation of photovoltaic systems developed by Valentin Software. In addition to $\mathrm{PV} * \mathrm{SOL}$, this company has other software tools for solar thermal systems (T*SOL) and geothermal solar systems (GeoT*SOL). PV*SOL offers the possibility of configuring different types of PV systems, i.e., stand-alone systems with or without backup generator, grid-connected systems, and grid-connected systems with electrical appliances, which can include battery systems and electric vehicles [38].

Site-dependent climate data supplied by $\mathrm{PV} * \mathrm{SOL}$ is based on Meteonorm database. It is also possible to load user-defined climate data measured at a specific meteorological station. There is a premium version of the program, $\mathrm{PV} * \mathrm{SOL}$ premium, for $3 \mathrm{D}$ design of the system including environmental obstacles that can influence the irradiation received on the PV module.

When simulating the electrical production of the system and its performance, there is a choice between 8 models for the calculation of the diffuse component of the solar irradiation and 5 models (Liu and Jordan, Hay and Davies, Klucher, Perez et al., and Reindl) $[24,31,39-42]$ for the estimation of irradiance received on the tilted plane. A single annual albedo value may be included or modified for each month of the year. Both annual and monthly soiling losses can also be included. The software can be used to select the temporal resolution of the simulation: hourly (faster) or each minute (greater accurate).

The software also has an extensive database of PV modules, inverters, storage systems, and other devices. New devices can be defined for inclusion in the project. Regarding the $\mathrm{PV}$ modules, $\mathrm{PV}{ }^{*} \mathrm{SOL}$ allows the configuration of different types of installation, i.e., fixed, with a single-axis tracking system, and with a dual-axis tracking system. The inverter 
configuration includes the definition of the interconnection of the PV modules. Although not mandatory, it is also possible to consider wiring losses.

Once all the elements of the installation are defined, the program checks that the system is correct, and the simulation can proceed. The output data includes the predicted electrical production of the system, its performance ratio, the irradiance received on the module's plane and its temperature, a general energy balance of the system, and a financial analysis of the installation. Finally, it is possible to generate a report detailing the configuration of the system, its electrical diagrams, and the results. PV ${ }^{*} \mathrm{SOL}$ is subscription software and has a 30-day trial version.

\section{The Facilities}

This case study involves three facilities (System 1, System 2, and System 3) located slightly to the north from the center of the Spanish autonomous region of Castile and Leon, at the city of Palencia (System 1), at Torquemada (Palencia) (System 2), and at Los Balbases (Burgos) (System 3). The map locations are shown in Figure 1. The facilities are subject to very similar environmental conditions, in terms of temperature, solar irradiation, humidity, and wind speed. Solar irradiation is estimated at approximately $1450 \mathrm{kWh} / \mathrm{m}^{2}$ year [9]. The ambient temperature range is between $4{ }^{\circ} \mathrm{C}$ and $20^{\circ} \mathrm{C}$ and the number of cloudy days is very low [43]. Figures 2 and 3 and Figure 4 show photographs of the three facilities.

As can be seen in Figures 2 and 3 and Figure 4, all the facilities in this study have different types of sun-tracking technology. System 1, located at Palencia City, is a $38.88 \mathrm{~kW}_{\mathrm{p}}$ peak power fixed roof solar facility. It is composed of $218 \mathrm{PV}$ panels (model FOTONA 180D) tilted at $20^{\circ}$ and has an electrical performance of $12 \%$. System 1 uses six $7 \mathrm{~kW}_{\mathrm{p}}$ model SMC 7000TL inverters.

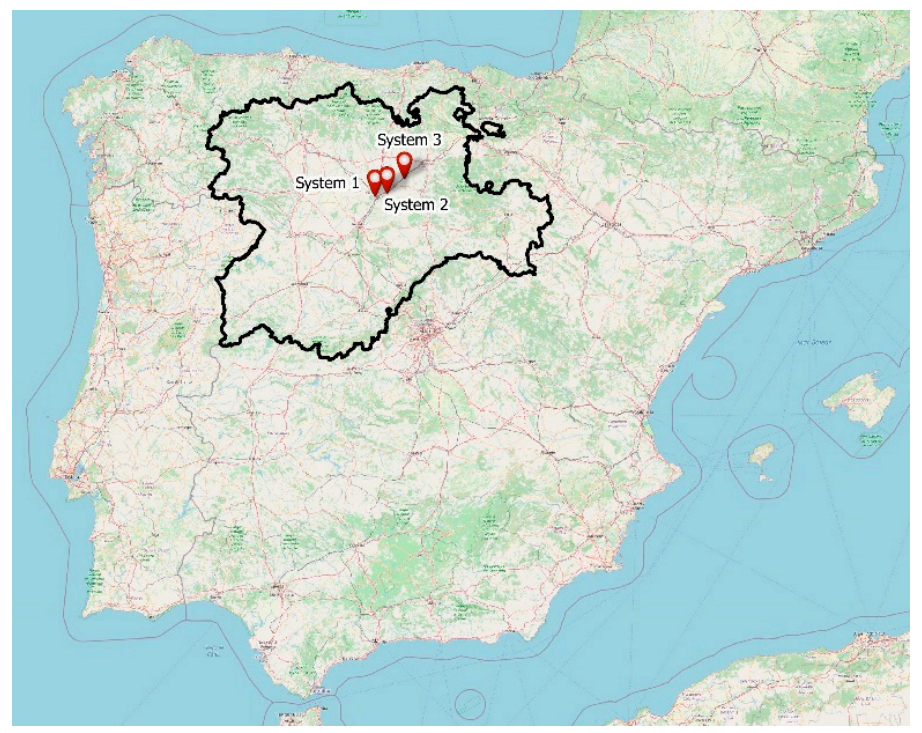

Figure 1. Geographical location of the three facilities.

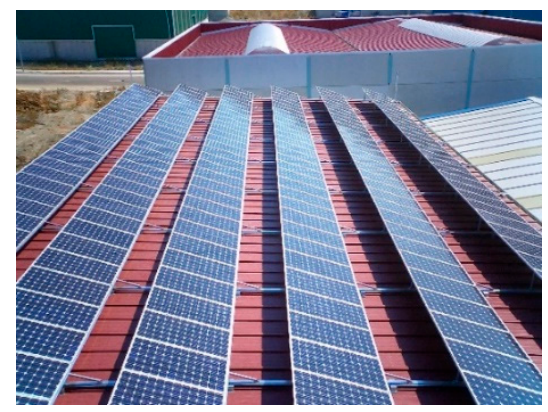

Figure 2. System 1 facility located in the city of Palencia. Fixed roof panels. 


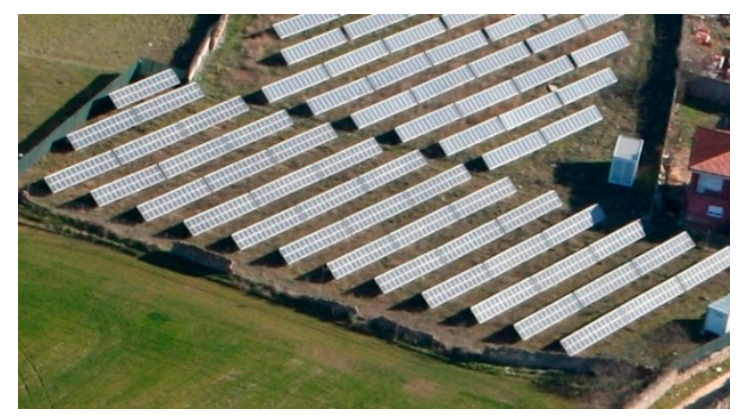

Figure 3. System 2 facility located at Torquemada (Palencia). One-axis, manual stational tilt.

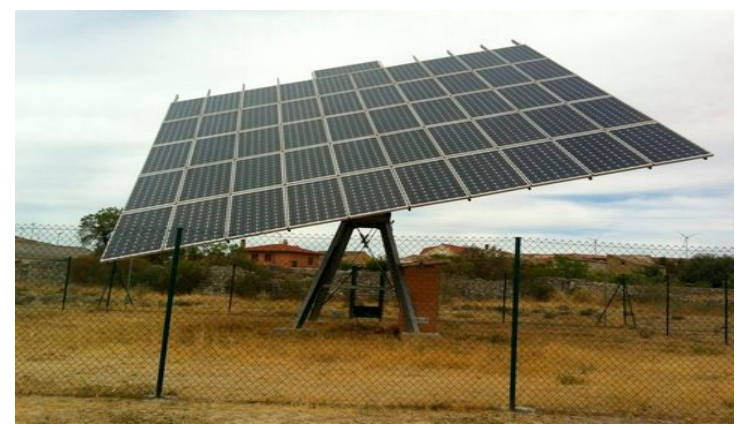

Figure 4. System 3 facility located at Los Balbases (Burgos). Two-axis sun tracker.

System 2, located at Torquemada (Palencia), is a $101.01 \mathrm{~kW}_{\mathrm{p}}$ power plant on the ground. It has a support structure, with which the panels can be manually adjusted in steps of $5^{\circ}$ to inclinations between $15^{\circ}$ and $55^{\circ}$ thereby optimizing the angle of incidence throughout the year, approximately once per month with the optimal tile angle for each month. System 2 is composed of 546 PV panels (model BP-7185S), 15\% electrical performance. Only one $100 \mathrm{~kW}$ inverter was selected, Ingecom Sun 100 Model.

System 3, located at Los Balbases (Burgos), is a 2-axis sun-tracker facility with 51 modules and an electrical performance of $14 \%$ that can generate $14.28 \mathrm{~kW}_{\mathrm{p}}$ (model Sunport $72 \mathrm{M})$. It has three $4.4 \mathrm{~kW}_{\mathrm{p}}$ Sunny Boy $4200 \mathrm{TL}$ HC inverters. The technical specifications of each of the three systems are summarized in Table 2.

\section{Real Exported Energy Data}

As previously mentioned, the real values of the energy exported to the grid were used as a reference. All the systems were set between 2006 and 2008, therefore the data period used for the study was from 2008 to 2020. Due to the length of the analysis, the influence of warm or cold years is not relevant. For that reason, average values can be considered as a typical average year of each power plant.

For each system, daily AC energy exported to the grid is available. However, as only monthly production may be modelled with most programs, the monthly average represented in Figure 5 was calculated for each installation. As mentioned above, the facilities have different nominal power capacities, therefore, to homogenize the data, all the values were divided by the installed power capacity of each system.

The energy generated is higher in systems that have some type of solar tracking. However, in the case of the two-axis tracker (System 3), it is penalized during cold months due to windy days. These elements go into safe mode when the wind is high, reducing the amount of energy that is generated. However, during summer months, this fact is not so frequent achieving considerably higher generation levels. It should also be noted that tracking facilities require more maintenance and have higher failure rates. Therefore, longterm production differences are never as high as may be expected. In Table 3, total energy generated in a year and the total production for each installed $\mathrm{kW}_{\mathrm{p}}$ are both included. 


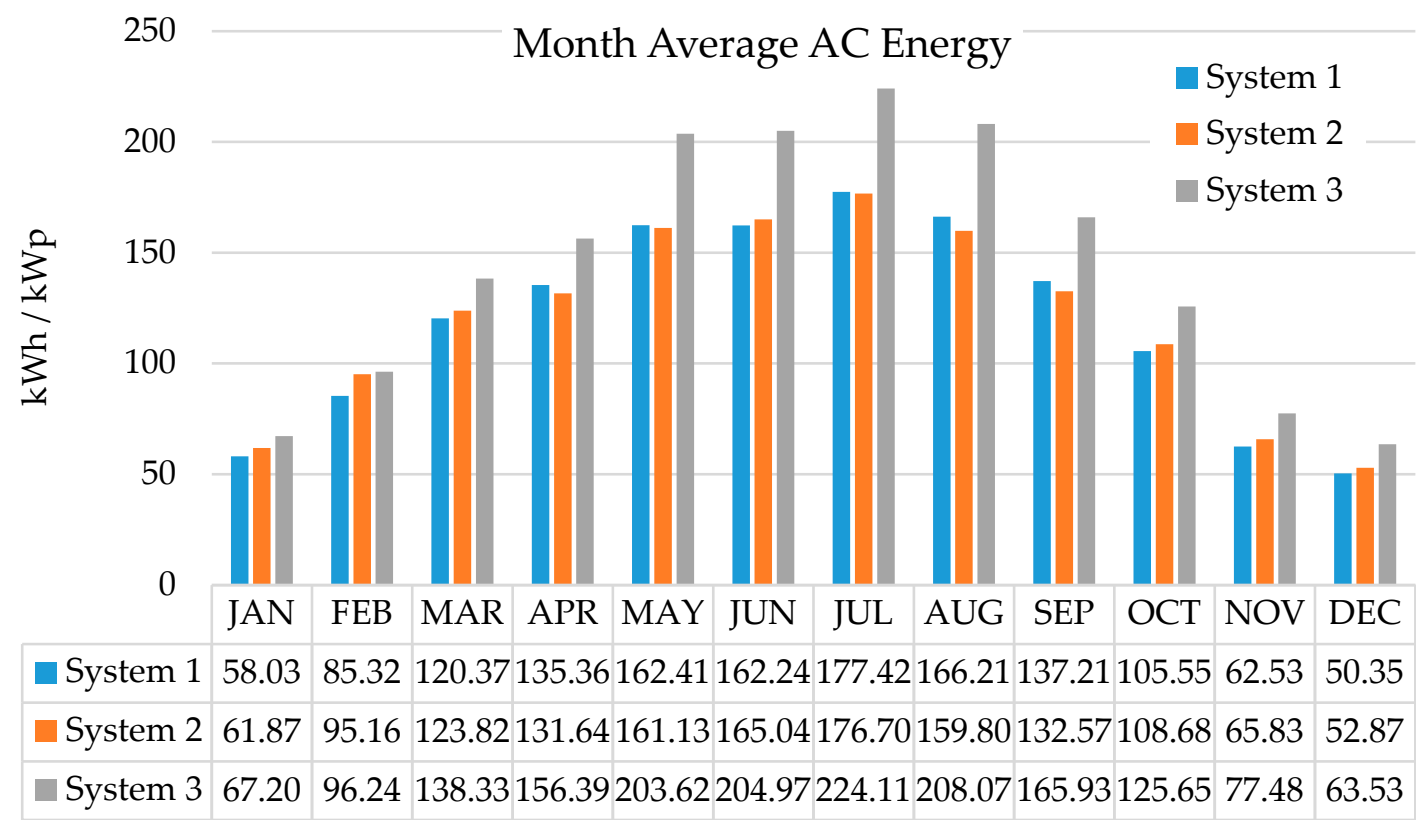

Figure 5. Monthly average energy supplied to the grid for the three systems under analysis. Values shown for each nominal $\mathrm{kW}$ installed.

Table 3. Yearly energy production of each system.

\begin{tabular}{ccc}
\hline & $\mathbf{k W h} /$ Year & $\mathbf{( k W h / Y e a r ) / \mathbf { k }} \mathbf{p}_{\mathbf{p}}$ \\
\hline System 1 & 55,445 & 1426 \\
System 2 & 144,962 & 1435 \\
System 3 & 24,726 & 1732 \\
\hline
\end{tabular}

\section{Results and Discussion}

The results of the different models under analysis were compared with the real data from the facilities. The comparison includes results obtained from all climate models available in SAM (isotropic, Perez, HDKR) and all climate databases included in PVGIS and PVSYST. PV*SOL was set with the Perez radiation model, since it is optimal in this study. In total, 11 studies were performed for each PV installation.

One of the most widely used values when assessing the suitability of a PV project, is the amount of electrical energy that can be generated throughout a year. Table 4 shows the total annual results obtained from the different models, in addition to the percentage deviation from the actual value for each system.

The results showed large differences depending on the type of sun-tracking technology. In general, the deviation obtained for System 1 (fixed) was low. The simplicity of this installation, in addition to the low operating uncertainty, meant that the simulations could be adjusted with deviations of below 5\%. Except for PV*SOL and RETScreen, the results obtained were slightly conservative, estimating lower energy productions.

In System 2 (1 axis), the results showed greater deviation. This installation incorporates a manual tilt adjustment that increases uncertainty due to system operation errors. However, despite this factor, the deviation was still lower than $10 \%$.

Finally, the most complex system had the 2-axis solar tracker (System 3). This type of facility is highly conditioned by the wind velocity, which, together with the greater probability of failures in these devices, reduces the availability of the facility. Therefore, the results obtained by the models considerably overestimated the energy generated, even above $20 \%$.

When the program results were individually analyzed, the results of the free software were generally better. In general, these models are simpler, benefiting from the type of 
preliminary study carried out (with a low number of predefined parameters). Although PVGIS is the simplest software, its results were excellent when using the COSMO database.

Table 4. Yearly energy results comparative of each system.

\begin{tabular}{|c|c|c|c|c|c|c|c|}
\hline \multicolumn{8}{|c|}{ AC Energy Generated in a Year $(\mathbf{k W h} / \mathbf{k W})$} \\
\hline & & \multicolumn{2}{|c|}{ P1 } & \multicolumn{2}{|c|}{ T1 } & \multicolumn{2}{|c|}{ L1 } \\
\hline $\begin{array}{l}\text { Actual } \\
\text { Value }\end{array}$ & $\begin{array}{c}\text { Average } \\
\text { Year }\end{array}$ & \multicolumn{2}{|c|}{$1426 \mathrm{kWh} / \mathrm{kW}_{\mathrm{p}}$} & \multicolumn{2}{|c|}{$1435 \mathrm{kWh} / \mathrm{kW}_{\mathrm{p}}$} & \multicolumn{2}{|c|}{$1732 \mathrm{kWh} / \mathrm{kW}_{\mathrm{p}}$} \\
\hline Software & Options & $\mathbf{k W h} / \mathbf{k W}_{\mathrm{p}}$ & Deviation & $\mathbf{k W h} / \mathbf{k W}$ & Deviation & $\mathbf{k W h} / \mathbf{k W}_{\mathrm{p}}$ & Deviation \\
\hline RETScreen & - & 1479 & $3.72 \%$ & 1547 & $7.79 \%$ & 1761 & $1.68 \%$ \\
\hline \multirow{3}{*}{ SAM } & ISOTROPIC & 1359 & $-4.73 \%$ & 1435 & $-0.04 \%$ & 1627 & $-6.05 \%$ \\
\hline & $H D K R$ & 1384 & $-2.96 \%$ & 1485 & $3.47 \%$ & 1753 & $1.21 \%$ \\
\hline & PEREZ & 1401 & $-1.76 \%$ & 1507 & $5.01 \%$ & 1796 & $3.73 \%$ \\
\hline \multirow{4}{*}{ PVGIS } & SARAH & 1439 & $0.93 \%$ & 1617 & $12.68 \%$ & 2073 & $19.73 \%$ \\
\hline & CMSAF & 1387 & $-2.73 \%$ & 1581 & $10.15 \%$ & 1983 & $14.55 \%$ \\
\hline & ERA5 & 1419 & $-0.48 \%$ & 1586 & $10.49 \%$ & 2111 & $21.92 \%$ \\
\hline & COSMO & 1302 & $-8.70 \%$ & 1427 & $-0.56 \%$ & 1752 & $1.19 \%$ \\
\hline \multirow{2}{*}{ PVSYST } & New & 1413 & $-0.95 \%$ & 1464 & $2.00 \%$ & 1953 & $12.80 \%$ \\
\hline & Classic & 1281 & $-10.20 \%$ & 1321 & $-7.93 \%$ & 1705 & $-1.53 \%$ \\
\hline $\mathrm{PV}^{*} \mathrm{SOL}$ & - & 1580 & $10.80 \%$ & 1590 & $10.82 \%$ & 1855 & $7.12 \%$ \\
\hline
\end{tabular}

The results provided by SAM showed the best global fit of the three systems under analysis. Specifically, regardless of the irradiation model in use, the deviation was less than $6 \%$. On the contrary, PV*SOL showed very high deviation values, overestimating by around $10 \%$ for all installations, but this deviation was consistent for the three systems under analysis.

\section{Monthly Results}

In addition, a comparison with monthly results was also performed. In this way, the results could be analyzed in more detail, so as to establish whether the deviation was balanced throughout the year. The deviation percentage from the actual monthly values are shown in Table 5 for the three systems. So that the interpretation of the large volume of data is easier, the cells in this table are color-coded. Red cells show results that were overestimated, blue cells show the underestimated ones.

An analysis of the monthly results showed that most models overestimated the energy generated during the winter months (when daylight hours and solar irradiation are lower), while they underestimated the results during summer, compensating the deviation throughout the year.

The model for fixed installations (System 1), as previously mentioned, showed very good results. The models that showed better results were SAM isotropic and PVSYST new. However, the results were consistent for most months. From November to January the results showed high deviations.

Despite the greater complexity of System 2 and therefore its higher operational uncertainty, due to possible orientation mismatch, in general, all the programs yielded accurate predictions in the warmer months. On the other hand, errors, even higher than $60 \%$, were obtained during the winter months. In this case, the model with the best results was SAM. It can therefore be deduced that none of the climate databases were accurate in wintertime.

Lastly, the results for System 3 were shown to be inconsistent. In this type of installation, the models provided very different values throughout the year. In May, the deviation increased in all the models. Spring is usually windy; therefore, the solar tracker automatically activated save mode and was not correctly oriented. RETScreen and PVGIS COSMO provided the best results during the different months of the year. 
Table 5. Monthly average energy production of each system.

\begin{tabular}{|c|c|c|c|c|c|c|c|c|c|c|c|}
\hline \multicolumn{12}{|c|}{ System 1 (FIX) [\%] } \\
\hline \multirow{2}{*}{ Month } & \multirow{2}{*}{ RETScreen } & \multicolumn{3}{|c|}{ SAM } & \multicolumn{4}{|c|}{ PVGIS } & \multicolumn{2}{|c|}{ PVSYST } & \multirow{2}{*}{ PV*SOL } \\
\hline & & Isotropic & HDKR & Perez & $S A R A H$ & CMSAF & ERA5 & COSMO & New & Classic & \\
\hline Jan & $21.1 \%$ & $-5.0 \%$ & $-0.2 \%$ & $1.8 \%$ & $9.8 \%$ & $-3.5 \%$ & $6.6 \%$ & $-3.8 \%$ & $0.6 \%$ & $1.0 \%$ & $18.1 \%$ \\
\hline Feb & $2.2 \%$ & $-12.3 \%$ & $-8.7 \%$ & $-7.3 \%$ & $-1.3 \%$ & $-10.1 \%$ & $-5.1 \%$ & $-12.8 \%$ & $-5.4 \%$ & $-16.8 \%$ & $4.7 \%$ \\
\hline Mar & $7.6 \%$ & $-9.0 \%$ & $-6.6 \%$ & $-5.4 \%$ & $2.1 \%$ & $-2.4 \%$ & $1.3 \%$ & $-6.3 \%$ & $2.6 \%$ & $-1.7 \%$ & $5.4 \%$ \\
\hline Apr & $4.0 \%$ & $-6.1 \%$ & $-4.7 \%$ & $-3.5 \%$ & $-2.2 \%$ & $-7.2 \%$ & $1.3 \%$ & $-8.0 \%$ & $-5.0 \%$ & $-9.9 \%$ & $10.7 \%$ \\
\hline May & $-1.9 \%$ & $-5.1 \%$ & $-4.5 \%$ & $-3.3 \%$ & $-4.8 \%$ & $-6.3 \%$ & $-3.2 \%$ & $-9.4 \%$ & $-7.4 \%$ & $-12.6 \%$ & $8.3 \%$ \\
\hline Jun & $6.3 \%$ & $-1.1 \%$ & $-1.0 \%$ & $-0.1 \%$ & $-2.0 \%$ & $-3.4 \%$ & $-3.3 \%$ & $-7.2 \%$ & $-0.9 \%$ & $-9.3 \%$ & $10.9 \%$ \\
\hline Jul & $1.5 \%$ & $-0.6 \%$ & $-0.3 \%$ & $0.7 \%$ & $-1.0 \%$ & $-1.6 \%$ & $-2.7 \%$ & $-8.1 \%$ & $-0.7 \%$ & $-12.9 \%$ & $12.4 \%$ \\
\hline Ago & $0.5 \%$ & $-0.7 \%$ & $0.3 \%$ & $1.3 \%$ & $-0.5 \%$ & $-2.0 \%$ & $-1.8 \%$ & $-8.6 \%$ & $-1.3 \%$ & $-13.2 \%$ & $13.7 \%$ \\
\hline Sep & $0.3 \%$ & $-9.6 \%$ & $-7.6 \%$ & $-6.7 \%$ & $-1.2 \%$ & $-2.7 \%$ & $-2.5 \%$ & $-13.0 \%$ & $-0.8 \%$ & $-12.6 \%$ & $6.0 \%$ \\
\hline Oct & $-6.5 \%$ & $-7.9 \%$ & $-4.8 \%$ & $-3.8 \%$ & $0.3 \%$ & $-2.1 \%$ & $-1.0 \%$ & $-14.7 \%$ & $-1.8 \%$ & $-10.3 \%$ & $9.5 \%$ \\
\hline Nov & $16.8 \%$ & $8.4 \%$ & $13.6 \%$ & $15.3 \%$ & $15.8 \%$ & $6.8 \%$ & $7.2 \%$ & $-7.0 \%$ & $10.2 \%$ & $-2.5 \%$ & $31.0 \%$ \\
\hline Dec & $18.9 \%$ & $-12.6 \%$ & $-7.9 \%$ & $-5.3 \%$ & $28.8 \%$ & $16.1 \%$ & $17.1 \%$ & $2.6 \%$ & $16.0 \%$ & $-11.1 \%$ & $9.7 \%$ \\
\hline Average & $5.9 \%$ & $-5.1 \%$ & $-2.7 \%$ & $-1.4 \%$ & $3.6 \%$ & $-1.5 \%$ & $1.2 \%$ & $-8.0 \%$ & $0.5 \%$ & $-9.3 \%$ & $11.7 \%$ \\
\hline \multicolumn{12}{|c|}{ System 2 (1 Axis) [\%] } \\
\hline \multirow{2}{*}{ Month } & \multirow{2}{*}{ RETScreen } & \multicolumn{3}{|c|}{ SAM } & \multicolumn{4}{|c|}{ PVGIS } & \multicolumn{2}{|c|}{ PVSYST } & \multirow{2}{*}{ PV*SOL } \\
\hline & & Isotropic & $H D K R$ & Perez & $S A R A H$ & CMSAF & ERA5 & COSMO & New & Classic & \\
\hline Jan & $40.4 \%$ & $7.2 \%$ & $18.5 \%$ & $21.8 \%$ & $41.0 \%$ & $20.2 \%$ & $34.8 \%$ & $13.4 \%$ & $15.5 \%$ & $15.2 \%$ & $40.7 \%$ \\
\hline Feb & $7.5 \%$ & $-6.9 \%$ & $1.1 \%$ & $3.3 \%$ & $11.5 \%$ & $3.3 \%$ & $7.2 \%$ & $-4.3 \%$ & $1.7 \%$ & $-11.6 \%$ & $5.9 \%$ \\
\hline Mar & $8.2 \%$ & $-6.6 \%$ & $-2.3 \%$ & $-0.5 \%$ & $9.4 \%$ & $8.2 \%$ & $9.5 \%$ & $-0.3 \%$ & $5.5 \%$ & $0.7 \%$ & $1.3 \%$ \\
\hline Apr & $5.8 \%$ & $-2.6 \%$ & $-0.9 \%$ & $0.6 \%$ & $4.5 \%$ & $2.9 \%$ & $8.2 \%$ & $-2.0 \%$ & $-4.5 \%$ & $-9.8 \%$ & $4.9 \%$ \\
\hline May & $-1.6 \%$ & $-3.3 \%$ & $-2.9 \%$ & $-2.0 \%$ & $1.1 \%$ & $2.7 \%$ & $1.3 \%$ & $-5.5 \%$ & $-8.5 \%$ & $-14.6 \%$ & $2.2 \%$ \\
\hline Jun & $4.6 \%$ & $-1.4 \%$ & $-1.3 \%$ & $-0.7 \%$ & $1.6 \%$ & $2.2 \%$ & $-0.4 \%$ & $-4.2 \%$ & $-4.6 \%$ & $-13.0 \%$ & $4.5 \%$ \\
\hline Jul & $1.7 \%$ & $1.0 \%$ & $1.2 \%$ & $1.9 \%$ & $5.0 \%$ & $5.5 \%$ & $2.8 \%$ & $-2.9 \%$ & $-0.3 \%$ & $-12.6 \%$ & $8.4 \%$ \\
\hline Ago & $3.2 \%$ & $3.7 \%$ & $4.6 \%$ & $5.7 \%$ & $8.7 \%$ & $7.5 \%$ & $6.4 \%$ & $-1.0 \%$ & $0.4 \%$ & $-10.8 \%$ & $12.4 \%$ \\
\hline Sep & $5.0 \%$ & $-2.5 \%$ & $0.8 \%$ & $2.3 \%$ & $11.2 \%$ & $11.3 \%$ & $9.4 \%$ & $-2.7 \%$ & $3.1 \%$ & $-8.1 \%$ & $6.4 \%$ \\
\hline Oct & $-1.2 \%$ & $1.3 \%$ & $8.1 \%$ & $9.8 \%$ & $19.0 \%$ & $15.1 \%$ & $15.7 \%$ & $-4.3 \%$ & $1.1 \%$ & $-8.0 \%$ & $12.2 \%$ \\
\hline Nov & $33.8 \%$ & $24.5 \%$ & $36.6 \%$ & $39.6 \%$ & $45.2 \%$ & $36.3 \%$ & $33.5 \%$ & $9.6 \%$ & $19.3 \%$ & $5.6 \%$ & $50.1 \%$ \\
\hline Dec & $40.1 \%$ & $-2.0 \%$ & $9.1 \%$ & $13.7 \%$ & $67.5 \%$ & $59.0 \%$ & $59.3 \%$ & $28.9 \%$ & $37.3 \%$ & $0.2 \%$ & $30.5 \%$ \\
\hline Average & $12.3 \%$ & $1.0 \%$ & $6.0 \%$ & $8.0 \%$ & $18.8 \%$ & $14.5 \%$ & $15.6 \%$ & $2.1 \%$ & $5.5 \%$ & $-5.6 \%$ & $14.9 \%$ \\
\hline \multicolumn{12}{|c|}{ System 3 (2 Axis) [\%] } \\
\hline \multirow{2}{*}{ Month } & \multirow{2}{*}{ RETScreen } & \multicolumn{3}{|c|}{ SAM } & \multicolumn{4}{|c|}{ PVGIS } & & YST & \\
\hline & & Isotropic & $H D K R$ & Perez & $S A R A H$ & CMSAF & ERA5 & COSMO & New & Classic & $\mathbf{L}$ \\
\hline Jan & $13.3 \%$ & $-14.6 \%$ & $-4.2 \%$ & $2.4 \%$ & $36.2 \%$ & $14.8 \%$ & $48.8 \%$ & $11.6 \%$ & $21.9 \%$ & $23.0 \%$ & $22.9 \%$ \\
\hline Feb & $-4.8 \%$ & $-15.9 \%$ & $-6.4 \%$ & $-3.5 \%$ & $27.6 \%$ & $10.2 \%$ & $26.7 \%$ & $3.5 \%$ & $17.2 \%$ & $3.3 \%$ & $2.4 \%$ \\
\hline Mar & $3.0 \%$ & $-8.0 \%$ & $-0.2 \%$ & $2.2 \%$ & $23.1 \%$ & $17.7 \%$ & $26.9 \%$ & $6.8 \%$ & $21.0 \%$ & $14.4 \%$ & $-1.2 \%$ \\
\hline Apr & $3.3 \%$ & $-10.7 \%$ & $-4.6 \%$ & $-2.5 \%$ & $15.9 \%$ & $8.9 \%$ & $24.6 \%$ & $1.4 \%$ & $8.8 \%$ & $-0.6 \%$ & $-7.7 \%$ \\
\hline May & $-11.8 \%$ & $-14.0 \%$ & $-8.8 \%$ & $-6.3 \%$ & $8.2 \%$ & $6.2 \%$ & $10.9 \%$ & $-3.4 \%$ & $2.1 \%$ & $-9.2 \%$ & $-7.2 \%$ \\
\hline Jun & $0.3 \%$ & $-1.8 \%$ & $3.8 \%$ & $5.6 \%$ & $11.5 \%$ & $10.4 \%$ & $14.4 \%$ & $0.0 \%$ & $9.3 \%$ & $-4.3 \%$ & $10.4 \%$ \\
\hline Jul & $-1.4 \%$ & $1.9 \%$ & $7.9 \%$ & $10.3 \%$ & $17.1 \%$ & $17.7 \%$ & $17.2 \%$ & $2.5 \%$ & $11.9 \%$ & $-7.5 \%$ & $17.0 \%$ \\
\hline Ago & $2.4 \%$ & $3.9 \%$ & $10.8 \%$ & $11.9 \%$ & $17.2 \%$ & $16.2 \%$ & $17.0 \%$ & $0.2 \%$ & $9.7 \%$ & $-9.5 \%$ & $17.0 \%$ \\
\hline Sep & $8.6 \%$ & $-6.1 \%$ & $1.1 \%$ & $3.9 \%$ & $17.9 \%$ & $15.9 \%$ & $17.5 \%$ & $-2.9 \%$ & $11.8 \%$ & $-4.6 \%$ & $5.8 \%$ \\
\hline Oct & $0.6 \%$ & $-8.2 \%$ & $0.6 \%$ & $3.4 \%$ & $21.9 \%$ & $17.0 \%$ & $24.3 \%$ & $-4.7 \%$ & $13.1 \%$ & $0.9 \%$ & $5.1 \%$ \\
\hline Nov & $25.2 \%$ & $-2.2 \%$ & $10.0 \%$ & $13.4 \%$ & $34.9 \%$ & $19.7 \%$ & $32.5 \%$ & $0.5 \%$ & $22.9 \%$ & $9.4 \%$ & $17.8 \%$ \\
\hline Dec & $4.1 \%$ & $-15.4 \%$ & $-4.3 \%$ & $-0.9 \%$ & $55.3 \%$ & $36.9 \%$ & $55.0 \%$ & $14.3 \%$ & $36.7 \%$ & $-1.0 \%$ & $14.2 \%$ \\
\hline Average & $3.6 \%$ & $-7.6 \%$ & $0.5 \%$ & $3.3 \%$ & $23.9 \%$ & $16.0 \%$ & $26.3 \%$ & $2.5 \%$ & $15.5 \%$ & $1.2 \%$ & $8.1 \%$ \\
\hline
\end{tabular}

\section{Conclusions}

The values of the energy supplied to the grid from three photovoltaic power plants with different sun-tracking systems have been compared, over a period of 11 years, using the results from five computer software programs with which the energy production of photovoltaic systems can be modeled. In addition, the use of the different climate databases available by default in the programs have been included in the study. Thus, eleven different simulations were available. The computer tools under analysis included subscription and open access (free) versions.

The results of the simulations carried out using the subscription tools were not appreciably better than those obtained through free-to-use programs. However, these commercial programs present a more intuitive and simpler interface, in addition to having more pos- 
sibilities of incorporating different formats of climatic bases, and extensive and updated elements libraries (PV panels, inverters, etc.). One of the main advantages of these systems is the possibility of modeling the installation in detail, considering many aspects, and with very good results.

The most influential parameter in the simulation results was the climatic database for the area. PV*SOL presented high but very consistent errors, above $10 \%$. The model may therefore be calibrated to adjust to a set resolution.

The higher failure rate and safe position of the solar trackers reduce the amount of energy that is generated when there is a lot of wind. This aspect, which is difficult to predict, means that the results of all the simulations showed large differences with respect to the real production data. A model should be included with a coefficient of losses due to wind and system failures.

In addition, System 2 has a manual tilt change mechanism, which increases the losses due to errors with the adjustment of the tilt angle. Prediction of this aspect is very difficult in a global model and reduces the accuracy of these PV models.

In annual global terms, the results can occasionally hide bad predictions throughout the year, where overestimations are compensated by underestimated results. This fact was reflected in the monthly results of the different models that were not consistent. In general, during the colder months they were overestimated, while during the warmer months the models showed a better fit.

The best global results were from SAM and RETScreen. The deviations of both programs with respect to real data were lower than $10 \%$.

Author Contributions: Conceptualization and methodology, M.I.D.-V. and C.A.-T.; software, D.G.-P. and I.G.-R.; validation, D.G.-P. and I.G.-R.; formal analysis, D.G.-P., I.G.-R. and C.A.-T.; investigation, D.G.-P., I.G.-R., M.D.-M. and C.A.-T.; original draft preparation, D.G.-P. and I.G.-R.; writing-review and editing, M.I.D.-V. and C.A.-T.; visualization, D.G.-P. and I.G.-R.; supervision, M.D.-M. and C.A.-T.; project administration, M.D.-M.; funding acquisition, C.A.-T. All authors have read and agreed to the published version of the manuscript.

Funding: This research was funded by Spanish Ministry of Science and Innovation, grant number RTI2018-098900-B-I00 and the Regional Government of Castilla y León under the "Support Program for Recognized Research Groups of Public Universities of Castilla y León" (ORDEN EDU/667/2019) and "Health and Safety Program" (INVESTUN/19/BU/0004).

Institutional Review Board Statement: Not applicable.

Informed Consent Statement: Not applicable.

Conflicts of Interest: The authors declare no conflict of interest.

\section{References}

1. IEA (Internaional Energy Agency). World Energy Outlook-2017; IEA (Internaional Energy Agency): Paris, France, 2017.

2. Connolly, D.; Lund, H.; Mathiesen, B.V.; Leahy, M. A review of computer tools for analysing the integration of renewable energy into various energy systems. Appl. Energy 2010, 87, 1059-1082. [CrossRef]

3. Wijeratne, W.M.P.U.; Yang, R.J.; Too, E.; Wakefield, R. Design and development of distributed solar PV systems: Do the current tools work? Sustain. Cities Soc. 2019, 45, 553-578. [CrossRef]

4. Lee, G.R.; Frearson, L.; Rodden, P. An Assessment of Photovoltaic Modelling Software Using Real World Performance Data. In Proceedings of the 26th European Photovoltaic Solar Energy Conference and Exhibition, Hamburg, Germany, 5-6 September 2011; pp. 4339-4343.

5. Axaopoulos, P.J.; Fylladitakis, E.D.; Gkarakis, K. Accuracy analysis of software for the estimation and planning of photovoltaic installations. Int. J. Energy Environ. Eng. 2014, 5, 1. [CrossRef]

6. Freeman, J.; Whitmore, J.; Blair, N.; Dobos, A.P. Validation of multiple tools for flat plate photovoltaic modeling against measured data. In Proceedings of the 2014 IEEE 40th Photovoltaic Specialist Conference (PVSC), Denver, CO, USA, 8-13 June 2014; pp. 1932-1937.

7. Freeman, J.; Whitmore, J.; Kaffine, L.; Blair, N.; Dobos, A.P. System Advisor Model: Flat Plate Photovoltaic Performance Modeling Validation Report. NREL 2013, 129. [CrossRef] 
8. de Souza Silva, J.L.; Costa, T.S.; de Melo, K.B.; Sako, E.Y.; Moreira, H.S.; Villalva, M.G. A Comparative Performance of PV Power Simulation Software with an Installed PV Plant. In Proceedings of the 2020 IEEE International Conference on Industrial Technology (ICIT), Buenos Aires, Argentina, 26-28 February 2020; pp. 531-535.

9. Photovoltaic Geographical Information System (PVGIS) I EU Science Hub. Available online: https://ec.europa.eu/jrc/en/pvgis (accessed on 9 May 2021).

10. PVsyst-Logiciel Photovoltaïque. Available online: https://www.pvsyst.com/ (accessed on 9 May 2021).

11. RETScreen. Available online: https://www.nrcan.gc.ca/maps-tools-and-publications/tools/modelling-tools/retscreen/7465 (accessed on 9 May 2021).

12. Valentin Software PV*SOL. Available online: https://valentin-software.com/en/products/pvsol-premium/ (accessed on 9 May 2021).

13. NREL System Advisor Model (SAM). Available online: https:/ / sam.nrel.gov/ (accessed on 9 May 2021).

14. Šúri, M.; Huld, T.A.; Dunlop, E.D. PV-GIS: A web-based solar radiation database for the calculation of PV potential in Europe. Int. J. Sustain. Energy 2005, 24, 55-67. [CrossRef]

15. TamizhMani, G.; Ishioye, J.-P.; Voropayev, A.; Kang, Y. Photovoltaic performance models: An evaluation with actual field data. In Proceedings of the Reliability of Photovoltaic Cells, Modules, Components, and Systems SPIE, San Diego, CA, USA, 11-13 August 2008; Volume 7048, p. 70480W.

16. Djurdjevic, D.Z. Perspectives and assessments of solar PV power engineering in the Republic of Serbia. Renew. Sustain. Energy Rev. 2011, 15, 2431-2446. [CrossRef]

17. Hofierka, J.; Kaňuk, J. Assessment of photovoltaic potential in urban areas using open-source solar radiation tools. Renew. Energy 2009, 34, 2206-2214. [CrossRef]

18. Huld, T.; Müller, R.; Gambardella, A. A new solar radiation database for estimating PV performance in Europe and Africa. Sol. Energy 2012, 86, 1803-1815. [CrossRef]

19. Conceição, R.; Silva, H.G.; Fialho, L.; Lopes, F.M.; Collares-Pereira, M. PV system design with the effect of soiling on the optimum tilt angle. Renew. Energy 2019, 133, 787-796. [CrossRef]

20. Ozdemir, S.; Sahin, G. Multi-criteria decision-making in the location selection for a solar PV power plant using AHP. Meas. J. Int. Meas. Confed. 2018, 129, 218-226. [CrossRef]

21. Kumar, N.M.; Kumar, M.R.; Rejoice, P.R.; Mathew, M. Performance analysis of $100 \mathrm{kWp}$ grid connected Si-poly photovoltaic system using PVsyst simulation tool. In Proceedings of the Energy Procedia; Elsevier Ltd.: Abingdon, UK, 2017; Volume 117, pp. $180-189$.

22. Afanasyeva, S.; Bogdanov, D.; Breyer, C. Relevance of PV with single-axis tracking for energy scenarios. Sol. Energy 2018, 173, 173-191. [CrossRef]

23. Kumar, N.M.; Gupta, R.P.; Mathew, M.; Jayakumar, A.; Singh, N.K. Performance, energy loss, and degradation prediction of roofintegrated crystalline solar PV system installed in Northern India. Case Stud. Therm. Eng. 2019, 13, 100409. [CrossRef]

24. Perez, R.; Seals, R.; Ineichen, P.; Stewart, R.; Menicucci, D. A new simplified version of the perez diffuse irradiance model for tilted surfaces. Sol. Energy 1987, 39, 221-231. [CrossRef]

25. Hay, J.E. Calculation of monthly mean solar radiation for horizontal and inclined surfaces. Sol. Energy 1979, $23,301-307$. [CrossRef]

26. Tsai, S.C.; Chen, S.C.; Huang, K.F.; Hsu, C.H.; Liu, W.C.; Yu, C.C.; Chung, Y.N.; Chen, T.R. A new development of power converter for power management. ICIC Express Lett. 2011, 5, 3273-3277.

27. Praveen, R.P.; Abdul Baseer, M.; Awan, A.B.; Zubair, M. Performance Analysis and Optimization of a Parabolic Trough Solar Power Plant in the Middle East Region. Energies 2018, 11, 741. [CrossRef]

28. Okoye, C.O.; Bahrami, A.; Atikol, U. Evaluating the solar resource potential on different tracking surfaces in Nigeria. Renew. Sustain. Energy Rev. 2018, 81, 1569-1581. [CrossRef]

29. Marion, W.; Urban, K. User's Manual for TMY2s (Typical Meteorological Years)—Derived from the 1961-1990 National Solar Radiation Data Base; National Renewable Energy Lab. (NREL): Golden, CO, USA, 1995. [CrossRef]

30. Weather Data for Simulation I EnergyPlus. Available online: https://energyplus.net/weather/simulation (accessed on 9 May 2021).

31. Perez, R.; Ineichen, P.; Seals, R.; Michalsky, J.; Stewart, R. Modeling daylight availability and irradiance components from direct and global irradiance. Sol. Energy 1990, 44, 271-289. [CrossRef]

32. Reindl, D.T. Estimating Diffuse Radiation on Horizontal Surfaces and Total Radiation on Tilted Surfaces; University of Wisconsin: Madison, WI, USA, 1988.

33. Bakos, G.C. Distributed power generation: A case study of small scale PV power plant in Greece. Appl. Energy 2009, 86, 1757-1766. [CrossRef]

34. Bakos, G.C.; Soursos, M. Techno-economic assessment of a stand-alone PV/hybrid installation for low-cost electrification of a tourist resort in Greece. Appl. Energy 2002, 73, 183-193. [CrossRef]

35. EL-Shimy, M. Viability analysis of PV power plants in Egypt. Renew. Energy 2009, 34, 2187-2196. [CrossRef]

36. Zandi, M.; Bahrami, M.; Eslami, S.; Gavagsaz-Ghoachani, R.; Payman, A.; Phattanasak, M.; Nahid-Mobarakeh, B.; Pierfederici, S. Evaluation and comparison of economic policies to increase distributed generation capacity in the Iranian household consumption sector using photovoltaic systems and RETScreen software. Renew. Energy 2017, 107, 215-222. [CrossRef] 
37. Rehman, S.; Ahmed, M.A.; Mohamed, M.H.; Al-Sulaiman, F.A. Feasibility study of the grid connected $10 \mathrm{MW}$ installed capacity PV power plants in Saudi Arabia. Renew. Sustain. Energy Rev. 2017, 80, 319-329. [CrossRef]

38. García, I.; Torres, J.L. Temporal downscaling of test reference years: Effects on the long-term evaluation of photovoltaic systems. Renew. Energy 2018, 122, 392-405. [CrossRef]

39. Reindl, D.T.; Beckman, W.A.; Duffie, J.A. Evaluation of hourly tilted surface radiation models. Sol. Energy 1990, 45, 9-17. [CrossRef]

40. Klucher, T.M. Evaluation of models to predict insolation on tilted surfaces. Sol. Energy 1979, 23, 111-114. [CrossRef]

41. Hay, J.E. Calculating solar radiation for inclined surfaces: Practical approaches. Renew. Energy 1993, 3, 373-380. [CrossRef]

42. Liu, B.; Jordan, R. Daily insolation on surfaces tilted towards equator. ASHRAE J. 1961, 10, 5047843.

43. Meteotest Meteonorm Software Worldwide Irradiation Data. Available online: https://meteonorm.com/en/ (accessed on 9 May 2021). 